\title{
EFFECT OF N-ACETYL CYSTEINE ON OXIDATIVE STRESS AND Bax AND Bcl2 EXPRESSION IN THE KIDNEY TISSUE OF RATS EXPOSED TO LEAD
}

\author{
M. GHOLAMI', A. B. HARCHEGANI', S. SAEEDIAN ${ }^{3}$, \\ M. OWRANG ${ }^{4}$, M. R. PARVIZI
}

\author{
${ }^{1}$ Department of Physiology, Faculty of Medicine, \\ AJA University of Medical Sciences, Tehran, Iran; \\ ${ }^{2}$ Department of Medical Genetics, Faculty of Medicine, \\ Shahid Beheshti University of Medical Sciences, Tehran, Iran; \\ ${ }^{3}$ Medical Genomic Research Center, Tehran Medicine Sciences \\ Islamic Azad University, Tehran, Iran; \\ ${ }^{4}$ Faculty of Medicine, Sari Branch, Islamic Azad University, Sari, Iran; \\ e-mail: mparvizi@alumnus.tums.ac.ir
}

Received: 30 May 2020; Accepted: 17 December 2021

This study aimed to consider the lead-induced oxidative damage of the kidney of male rats and the role of antioxidant $N$-acetylcysteine (NAC) in preserving cells against $\mathrm{Pb}$ toxicity. Rats were randomly divided into five groups including G1 (control), G2 (single $70 \mathrm{mg} / \mathrm{kg}$ dose of Pb), G3 (continuous daily $2 \mathrm{mg} / \mathrm{kg}$ dosing of $\mathrm{Pb}$ for 4 weeks), G4 (single dose of $\mathrm{Pb}+50 \mathrm{mg} / \mathrm{kg} \mathrm{NAC}$ ), and G5 (continuous daily dosing of Pb $50 \mathrm{mg}$ / $\mathrm{kg} N A C)$. The level of malonic dialdehyde (MDA) and total antioxidant capacity were measured spectrophotometrically.The level of $\mathrm{Pb}$ in serum and kidney tissue was measured by atomic absorption spectroscopy. Expression of Bax and Bcl2 genes was estimated using RT-PCR. It was shown that single and continuous exposure to $\mathrm{Pb}$ caused a considerable increase of $\mathrm{Pb}$ content in serum and kidney tissue of rats in G2 and G3 groups compared to other groups. NAC treatment significantly improved TAC values and decreased MDA values in the serum of rats exposed to Pb. Single and continuous Pb dosing caused a 3.9- and 13.1-fold increase in Bax expression and 1.5-fold and 2.1-fold decrease in Bcl2 expression in a kidney tissue respectively. The current study revealed that single and especially continuous $\mathrm{Pb}$ exposure was strongly associated with $\mathrm{Pb}$ accumulation, antioxidant depletion, oxidative stress and kidney cells apoptosis. NAC can help protect kidney tissue against $\mathrm{Pb}$ by elevating antioxidant capacity, mitigating oxidative stress and normalizing Bax and Bcl2 genes expression.

Ke y w ord s: Pb, kidney, $N$-acetyl cysteine, oxidative stress, Bax, Bcl2, apoptosis.

L ead $(\mathrm{Pb})$ is a natural and potent environmental toxicant which is widespread in our environment from the air to soil and water $[1,2]$. Lead can be associated with a wide spectrum of complications or diseases such as neurological dysfunctions, hemolytic anemia, frank anemia, bone injury, renal failure, cardiovascular disease, cancers and reproductive problems [2-6]; however, the exact mechanism in which $\mathrm{Pb}$ mediates these abnormalities is not well-understood. Recent studies have proposed that $\mathrm{Pb}$ may induce cell injuries or toxicities through multiple mechanisms. Oxidative stress (OS) induced by overproduction of reactive oxygen species (ROS) and decreased effective concentration of antioxidants are considered as the main mechanisms of the $\mathrm{Pb}$ toxicity which can be ultimately associated with tissue cells apoptosis and injury [7]. Apoptosis is a programmed cellular death which is regulated by specific biochemical and molecular factors and occurs under both normal physiological conditions and physiological abnormalities. This process is controlled and induced by several internal and ex-

(C) 2021 Gholami M. et al. This is an open-access article distributed under the terms of the Creative Commons Attribution License, which permits unrestricted use, distribution, and reproduction in any medium, provided the original author and source are credited. 
ternal factors. The internal pathway includes genes that express proteins which are involved for the initiation (e.g. Bax) and inhibition of apoptosis (e.g. $\mathrm{Bcl} 2$ ) [8]. Bax and Bcl2 are well-known apoptotic proteins. While Bax is pro-apoptotic regulator and upon initiation of apoptotic signaling activates apoptosis, Bcl2 inhibits the release of cytochrome $\mathrm{C}$ from mitochondria and inhibits apoptosis. Higher $\mathrm{Bcl} 2 /$ Bax ratio is associated with increased survival rate of cells, whereas lower Bcl2/Bax ratio causes cells death [9]. Since oxidative stress is considered as one of the major factors for the induction of apoptosis, antioxidant supplementation may decrease apoptosis via the inhibition of $\mathrm{Pb}$-induced oxidative stress. $\mathrm{N}$-acetylcysteine (NAC) is a potential antioxidant that its anti-apoptotic properties have been recently studied by many researchers $[10,11]$. Given the potential role of $\mathrm{Pb}$ in tissues injury, it seems that oxidative stress induction and alterations in expression of Bax and Bcl2 genes may be a main mechanism of $\mathrm{Pb}$ toxicity. Based on reports, Bax and $\mathrm{Bcl} 2$ genes have important roles in the regulation of apoptosis and it seems that impaired expression of these proteins is one of the main causes of the negative effect of $\mathrm{Pb}$ on different tissues. As previous studies confirmed the antioxidant and anti-inflammatory effects of NAC, administration of this compound appears to reduce oxidative stress and reduce the expression of apoptotic biomarkers in various organs.

Although previous studies considered oxidative stress and expression of apoptosis makers in different models (e.g. rats with non-alcoholic fatty liver disease or diabetes) and tissues (e.g. liver), in this research we have focused on kidney tissue and effect of NAC supplementation at a same on these parameters which are not reported previously. Therefore, this study aimed to consider the effect of $\mathrm{Pb}$ on biomarkers of oxidative stress (e.g. total antioxidant and malondialdehyde levels) and expression of $\mathrm{Bax}$ and $\mathrm{Bcl} 2 \mathrm{in} \mathrm{Pb}$-treated rats. The therapeutic effect of NAC on these parameters will also be considered.

\section{Materials and Methods}

Animals. Thirty male Wistar rats with 8-10 weeks of age and body weight of 150-200 g were bought from the laboratory animal research center at Pasteur Institute of Iran (Tehran). This research was approved by the animal care and use committee at the Tehran Medicine Sciences Islamic Azad University. All rats were adapted with lab environment for one week and then randomly divided into
5 groups, including control (G1), G2 (single dose of $\mathrm{Pb}$ ), G3 (continuous daily dosing of $\mathrm{Pb}$ ), G4 (single dose of NAC $+\mathrm{Pb}$ ), and $\mathrm{G} 5$ (continuous daily dosing of $\mathrm{NAC}+\mathrm{Pb}$ ). Rats in each group were housed 3 per cage $(30 \times 15 \times 15 \mathrm{~cm})$ in a standard climate room (with temperature of $22 \pm 2^{\circ} \mathrm{C}$, humidity $50 \pm 5 \%$, and a 12:12 light/dark cycle) and had free access to food $(10 \mathrm{~g} / \mathrm{kg} /$ day $)$ and tab water.

Treatments. Rats in the control group were fed with normal pellet and water for 4 weeks. Rats in G1 group received a single gavage of $\mathrm{Pb}$ solution $(70 \mathrm{mg} / \mathrm{kg})$ on the first day of examination, while animals in G2 group received a continuous gavage of $\mathrm{Pb}$ solution $(2 \mathrm{mg} / \mathrm{kg})$ every other day for 4 weeks. Rats in G3 group received a combination of $\mathrm{Pb}(70 \mathrm{mg} / \mathrm{kg})$ and NAC $(50 \mathrm{mg} / \mathrm{kg})$ solutions at same time on the first day of examination, and rats in G4 group gained a continuous administration of $\mathrm{Pb}(2 \mathrm{mg} / \mathrm{kg})$ and NAC (50 mg/kg) solutions every other day for 4 weeks.

Tissues and blood samples collection. 48 hours after the final treatment, rats were anesthetized with xylasine $(3-5 \mathrm{mg} / \mathrm{kg})$ and ketamine $(30-50 \mathrm{mg} / \mathrm{kg})$ [12]. Blood samples were collected from the abdominal aorta for the assessment of serum $\mathrm{Pb}$ content. For histological study, kidney tissues were removed and fixed in 10\% formalin for at least 48 hours. Fragments were dehydrated in graded series of ethanol, embedded in paraffin and sectioned using an automatic microtome at 4-5 mm thickness. The sectioned tissues were stained with haematoxylin-eosin (H\&E) and evaluated for morphological and histological parameters by light microscope. A fragment of kidney tissue ( 100 mg) was separated and homogenized in phosphate buffer (with $\mathrm{pH} 7.0$ ) at $4^{\circ} \mathrm{C}$ with homogenizer (Hielscher, UP100H). The homogenized tissue was centrifuged at $12000 \mathrm{rpm} / 4^{\circ} \mathrm{C}$ for $15 \mathrm{~min}$ [13]. The supernatants were then collected and stored at $-80^{\circ} \mathrm{C}$ for further analysis.

Oxidative stress biomarkers. Total antioxidant capacity (TAC) in supernatants was determined by ferric reducing of antioxidant power (FRAP), which discussed previously by Benize et al., [14]. Malondialdehyde (MDA) level was measured using the thiobarbituric acid (TBA) method [15].

Measurement of $\mathrm{Pb}$. For the $\mathrm{Pb}$ analyses, kidney tissues ( $100 \mathrm{mg}$ ) were dried overnight at $75^{\circ} \mathrm{C}$ and then digested in approximately $10 \times$ the dry tissue mass of nitric acid. The digested samples were diluted 5-fold by deionized water. For the analysis of $\mathrm{Pb}$ in serum, blood samples were centrifuged at 
$600 \mathrm{~g}$ for $10 \mathrm{~min}$. After centrifugation, supernatants were diluted 5-fold by deionized water. Eventually, level of serum and kidney tissue $\mathrm{Pb}$ was measured by atomic absorption spectroscopy (AAS; Perkin Elmer model 2380). For $\mathrm{Pb}$ analysis, different concentrations of $\mathrm{Pb}$ (from $0.01-0.8 \mathrm{mg} / \mathrm{l}$ ) and for tissue $\mathrm{Pb}$ analysis, concentrations of $\mathrm{Pb}$ (from $0.01-0.8 \mu \mathrm{g}$ ) were used to plot the standard curve.

Gene expression analysis. RNX-Plus (SinaClon; RN7713C) Kit was used for total RNA extraction from homogenized kidney tissues. A Nanodrop ND-1000 spectrophotometer (Thermo Sci., Newington, $\mathrm{NH}$ ) was applied to consider the quantity and quality of extracted RNAs. Electrophoresis on $1 \%$ agarose gel was also performed to determine the quality of extracted RNAs. Revert Aid Reverse Transcriptase (Thermo science, Germ any) and random hexamer primers (Thermo science, Germ any) were used for cDNA synthesis at $42^{\circ} \mathrm{C}$ for $1 \mathrm{~h}$. A Rotor Gene 6000 (Corbett Research, Australia) thermocycler in 40 cycles was applied for amplifications. Each reaction included $5 \mu 1$ master mix and $100 \mathrm{nM}$ primers. Primer sequences are as follow: Bax, 5'-GAGGATGATTGCTGATGTGGATA-3' (forward), 5'-CAGTTGAAGTTGCCGTCTG-3' (reverse); Bcl2, 5'-GGAGCGTCAACAGGGAGATG-3' (forward), 5'-ACAGCCAGGAGAAATCAAACAGA-3' (reverse); and glyceraldehyde 3-phosphate dehydrogenase (GAPDH), 5'-AAGTTCAACGGCACAGTCAAGG-3' (forward); 5'-CATACTCAGCACCAGCATCACC-3' (reverse). The levels of mRNA were normalized relative to the amount of GAPDH mRNA. The relative expression of studied genes was calculated using $2^{-\Delta C t}$ method.

Statistical analysis. All data are presented as means \pm SD. One-Way ANOVA: Post Hoc-Tukey test was used to compare the mean of all data between groups. Data were analyzed using SPSS software (version 19). A $P<0.05$ was considered as significant.

\section{Results and Discussion}

Histopathological examination of kidney tissue in each group revealed that there were no abnormalities in the control group (G1), while sections of kidney tissue from rats in G3 group showed increased elevated inflammation. Although the sections of kidney from rats treated with NAC (G4 and G5) showed abnormalities, these concrete disorders were lower compared to the rats in G2 and G3 groups. Combined therapy with NAC declined number of inflammatory cells along with inflammation in kidney of rats exposed to $\mathrm{Pb}$ (Fig. 1). Single and continuous treatments with $\mathrm{Pb}$ caused a significant increase of Bowman capsule and glomerulus area. The mean of bowman capsule and glomerulus area in control group was $8257.03 \pm 1548.50 \mu \mathrm{m}^{2}$ and $6882.43 \pm 1398.21 \mu \mathrm{m}^{2}$, respectively. NAC supplementation significantly decreased Bowman capsule (from $11266.70 \pm 377.17 \mu \mathrm{m}^{2}$ to $9771.50 \pm 383.95 \mu \mathrm{m}^{2}$ ) and glomerulus area (from $8609.60 \pm 152.16 \mu \mathrm{m}^{2}$ to $7930.80 \pm 251.65 \mu \mathrm{m}^{2}$ ) of rats exposed to single dose of $\mathrm{Pb}$. The mean concentration of $\mathrm{Pb}$ in the kidney and serum of rats treated with single dose of NAC $+\mathrm{Pb}$ was relatively similar to that in control.

Comparison of FRAP value between all groups can be seen in Fig. 2. Rats treated with continuous dose of $\mathrm{Pb}$ had significantly lower mean values of FRAP value $(234.12 \pm 35.82 \mu \mathrm{g} / \mathrm{ml})$ compared to the other groups, while the mean level of FRAP in the kidney of rats in control group $(543.05 \pm 73.02 \mu \mathrm{g} / \mathrm{ml})$ was significantly higher than that in other groups. NAC treatments significantly improved FRAP values in rats that exposed to single (from $335.43 \pm 35.09 \mu \mathrm{g} / \mathrm{ml}$ to $473.72 \pm 70.35 \mu \mathrm{g}$ / $\mathrm{ml} ; P=0.002$ ) and continuous dose (from $234.12 \pm 35.82 \mu \mathrm{g} / \mathrm{ml}$ vs $291.75 \pm 41.87 \mu \mathrm{g} / \mathrm{ml}$; $P=0.043)$ of $\mathrm{Pb}$.

Fig. 3 shows comparison of MDA mean levels between all groups. While rats in control group had significantly lower mean levels of MDA $(17.26 \pm 3.22 \mu \mathrm{g} / \mathrm{ml})$ compared to the other groups, rats exposed to continuous dose of $\mathrm{Pb}$ had significantly higher MDA contents $(50.51 \pm 2.55 \mu \mathrm{g} / \mathrm{ml})$ than other groups. NAC treatments significantly decreased MDA values in rats that exposed to single (from $31.55 \pm 1.74 \mu \mathrm{g} / \mathrm{ml}$ to $23.81 \pm 1.46 \mu \mathrm{g}$ / $\mathrm{ml} ; P<0.001$ ) and continuous dose (from $50.51 \pm 2.55 \mu \mathrm{g} / \mathrm{ml}$ to $39.07 \pm 1.79 \mu \mathrm{g} / \mathrm{ml} ; P<0.001$ ) of $\mathrm{Pb}$.

A significant difference was found in expression pattern of Bax and Bcl2 between groups (Fig. 4 and 5). Rats treated with continuous and single dose of $\mathrm{Pb}$ showed significantly downregulation of $\mathrm{Bcl} 2$ and overexpression of Bax compared to the other groups. However, NAC treatments significantly improved the expression Bcl2 and decreased the expression of Bax in rats exposed to single or continuou $\mathrm{Pb}$.

Compared to control group, exposure to single and continuous dose of $\mathrm{Pb}$ caused a significant increase in Bax expression by 3.9-fold $(P=0.004)$ 

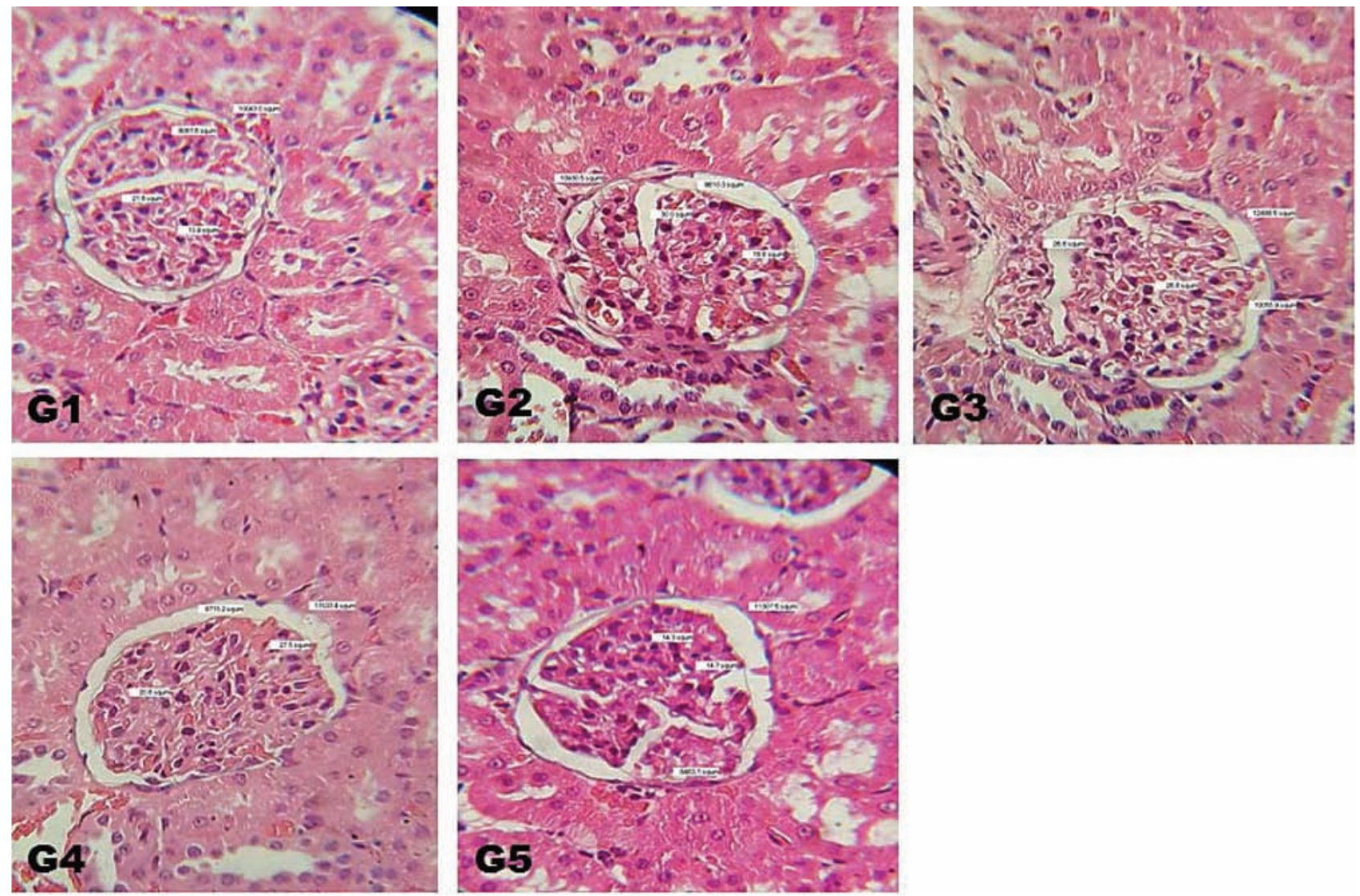

Fig. 1. Sections of kidney tissue from different groups. The kidney of rats in control (G1) were normal in structure, while sections from rats in continuous group (G2 and G3) showed increased elevated inflammatory cells, enlargement of bowman capsule and glomerulus area. Combined therapy with NAC declined number of inflammatory cells along with bowman capsule and glomerulus area in Pb exposed groups ( $G 4$ and G5). X20 magnification

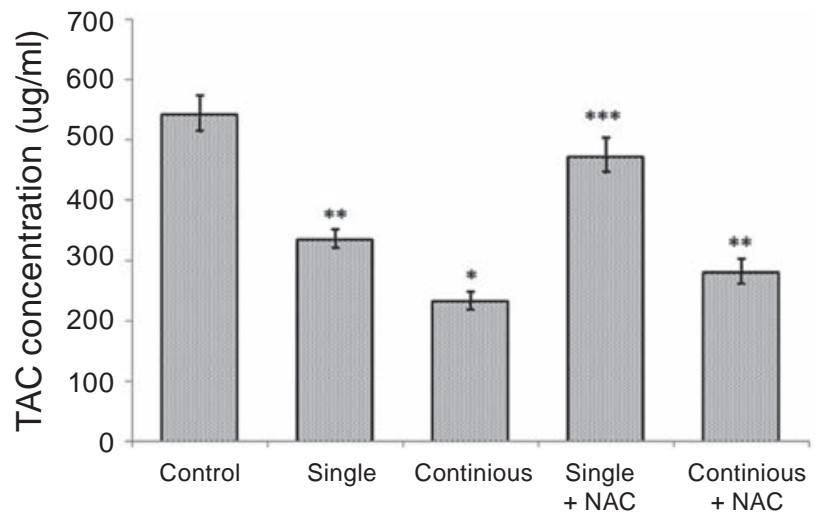

Fig. 2. Comparison of the mean of FRAP value in serum of rats in different groups. One-Way ANOVA: Post Hoc-Tukey test was applied to compare mean value of TAC between all groups. ${ }^{*} \mathrm{P}<0.001$; ${ }^{* *} P<0.01 ; * * * P<0.05$ compared to control group

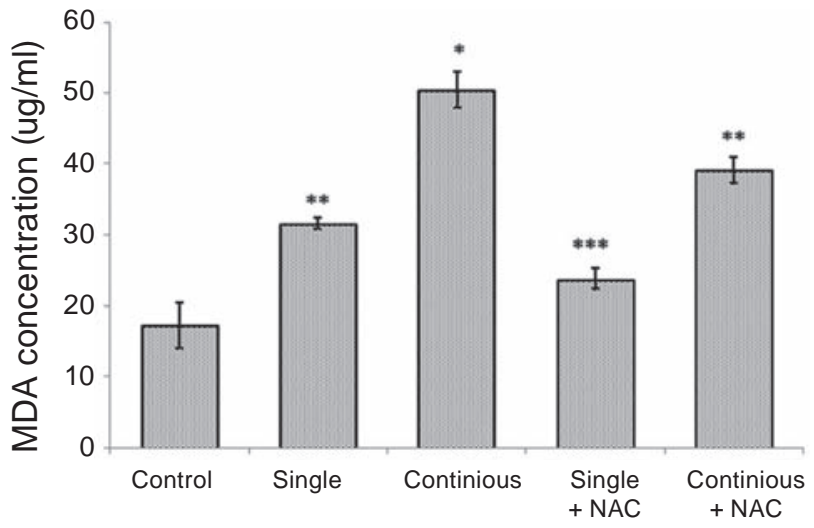

Fig. 3. Comparison of the mean of MDA value in serum of rats in different groups. One-Way ANOVA: Post Hoc-Tukey test was applied to compare mean value of MDA between all groups. ${ }^{*} P<0.001$; ${ }^{* *} P<0.01 ;{ }^{* * *} P<0.05$ compared to control group 
and 13.14-fold $(P<0.001)$, respectively. In contrast, rats that treated with a combination of NAC and $\mathrm{Pb}$ showed a mild decrease in Bax expression rather than to those treated with single or continuous dose $\mathrm{Pb}$. Bax expression in NAC + continuous $\mathrm{Pb}$ was significantly decreased by 1.98 -fold compared to the continuous $\mathrm{Pb}$ group $(P<0.0001$; Table 1$)$.

Single and continuous exposures to $\mathrm{Pb}$ significantly decreased the expression of Bcl2 compared to control by 1.49 -fold $(P=0.042)$ and 2.08 -fold $(P<0.001)$, respectively (Table 2$)$. However, NAC treatments significantly improved $B c l 2$ expression in the continuous group by 1.41 -fold $(P=0.042)$.

The mean of $\mathrm{Pb}$ concentrations in the blood and kidney tissue of rats exposed to single dose of $\mathrm{Pb}$ were $1.12 \pm 0.15 \mathrm{mg} / 1$ and $0.021 \pm 0.003 \mu \mathrm{g} / \mathrm{g}$ tissue, respectively, while the mean of $\mathrm{Pb}$ contents in the blood and kidney tissue of rats exposed to continuous $\mathrm{Pb}$ were $2.30 \pm 0.3 \mathrm{mg} / \mathrm{l}$ and $0.047 \pm 0.006 \mu \mathrm{g} / \mathrm{g}$ tissue, respectively (Fig. 6 and Fig. 7). NAC supplementation significantly decreased $\mathrm{Pb}$ concentrations in the both serum (from $1.12 \pm 0.15 \mathrm{mg} / \mathrm{l}$ to $0.65 \pm 0.11 \mathrm{mg} / \mathrm{l}$ ) and tissue samples (from $0.021 \pm 0.003 \mu \mathrm{g} / \mathrm{g}$ tissue to $0.018 \pm 0.001 \mu \mathrm{g} / \mathrm{g}$ tissue) of rats exposed to single dose of $\mathrm{Pb}$. The mean concentration of $\mathrm{Pb}$ in the kidney and serum of rats treated with $\mathrm{NAC}+$ single $\mathrm{Pb}$ dose was relatively similar to that in control. NAC supplementation significantly decreased $\mathrm{Pb}$ concentrations in the both serum (from $2.30 \pm 0.3 \mathrm{mg} / \mathrm{l}$ to $1.10 \pm 0.14 \mathrm{mg} / \mathrm{l}$ ) and tissue samples (from $0.047 \pm 0.006 \mu \mathrm{g} / \mathrm{g}$ tissue to

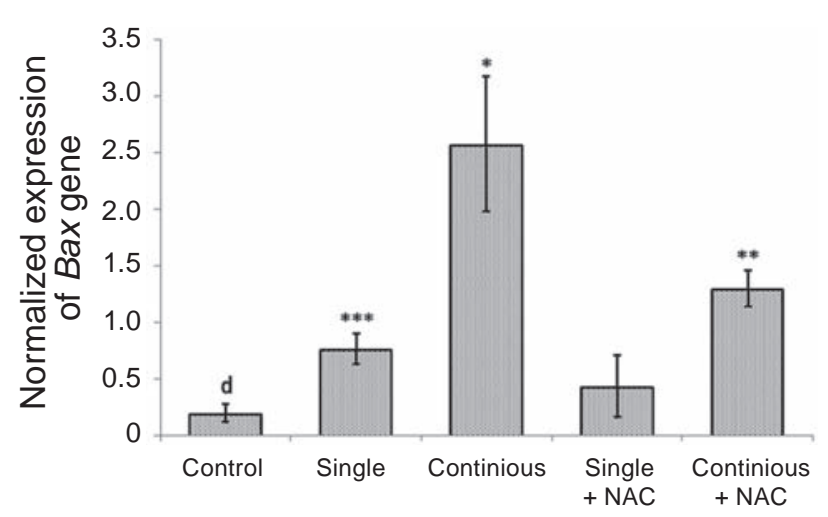

Fig. 4. Comparison of the mean mRNA levels of Bax. Gene expression was detected by Real-Time PCR. One-Way ANOVA: Post Hoc-Tukey test was applied to compare mean value of Bax expression pattern between all groups. ${ }^{*} P<0.001$; ${ }^{* *} P<0.01$; $* * * P<0.05$ compared to control group
$0.032 \pm 0.003 \mu \mathrm{g} / \mathrm{g}$ tissue) of rats exposed to continuous dose of $\mathrm{Pb}$.

In this study, we evaluated the effect of NAC supplementation on histological changes, oxidative stress biomarkers as well as expression patterns of $B a x$ and $B c l 2$ genes in the kidney tissue of rats exposed to single or continuous dose treatment of $\mathrm{Pb}$. Our findings have revealed that $\mathrm{Pb}$ exposure, especially continuous exposure, is associated with a significant depletion of total antioxidants and increased levels of MDA in the kidney tissue of study rats. Cd exposure, especially continuous exposure, was significantly associated with accumulation of kidney and blood $\mathrm{Pb}$ in exposed animals. We also found that $\mathrm{Pb}$ administration, especially at continuous dosing, significantly caused an overexpression of Bax and down-regulation of $B c l 2$ genes in the kidney tissue of exposed rats. Our findings support the idea that toxicological effect of $\mathrm{Pb}$ on kidney tissue is mediated through the induction of oxidative stress and renal cells apoptosis. Several lines of studies have demonstrated that $\mathrm{Pb}$ exposure has the both genotoxicity and cytotoxicity effects and induces oxidative stress and inflammation in different tissues [16]. For example, Kumar, et al., [17] demonstrated that $\mathrm{Pb}$ caused a significant increase in oxidative stress biomarkers in the liver of chicken. $\mathrm{Pb}$ exposure significantly increased the level of TBAR, and activity of glutathione peroxidase (GPX), GSH reductase, and catalase (CAT), but decreased the mean levels of glutathione (GSH) in the liver of exposed poultries [17]. Vitamin E + Selenium supplementation

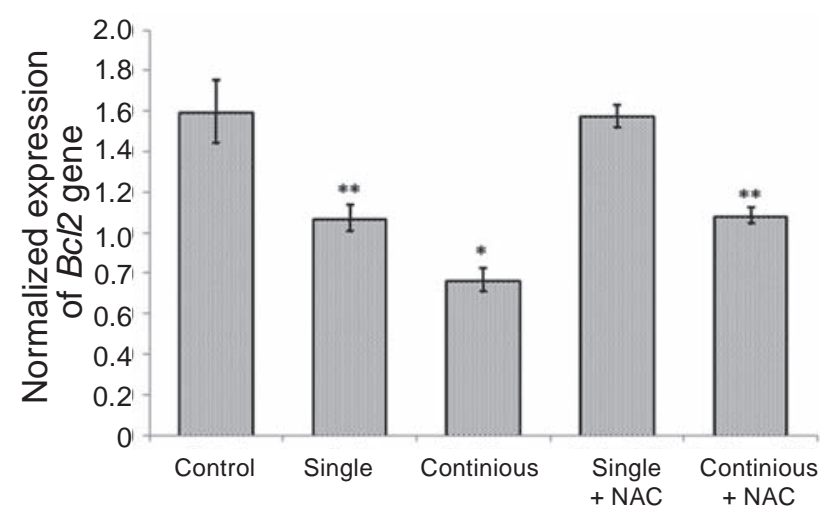

Fig. 5. Comparison of the mean mRNA levels of Bcl2. Gene expression was detected by Real-Time PCR. One-Way ANOVA: Post Hoc-Tukey test was applied to compare mean value of Bax expression pattern between all groups. ${ }^{*} P<0.001$; ${ }^{* *} P<0.01$ compared to control group 
Ta b le 1. Comparison of the fold change ratio of the Bax expression

\begin{tabular}{lcccc}
\hline \multicolumn{1}{c}{ Experimental groups } & Fold-change ratio & Up-/down-regulation & $P$-value \\
\hline Single vs control & 3.90 & Up-regulated & 0.004 \\
Continuous vs control & 13.14 & Up-regulated & $<0.001$ \\
NAC + single vs control & 2.24 & Up-regulated & 0.18 \\
NAC + continuous vs control & 6.62 & Up-regulated & $<0.001$ \\
Continuous vs Single & 3.37 & Up-regulated & $<0.001$ \\
Single vs NAC + continuous & 5.87 & Up-regulated & 0.006 \\
Single + NAC vs single & 1.74 & Down-regulated & 0.081 \\
Single + NAC vs continuous & 5.87 & Down-regulated & $<0.001$ \\
Single + NAC vs NAC + continuous & 2.96 & Down-regulated & $<0.001$ \\
Continuous + NAC vs continuous & 1.98 & Down-regulated & 0.038 \\
\hline
\end{tabular}

${ }^{*} P<0.05$ is considered as significant; One-Way ANOVA: Post Hoc-Tukey test was applied to compare mean value of Bax expression pattern between all groups

Ta ble 2. Comparison of the fold change ratio of the Bcl2 expression

\begin{tabular}{lcccc}
\hline \multicolumn{1}{c|}{ Experimental groups } & Fold-change ratio & Up-/down-regulation & $P$-value \\
\hline Single vs control & 1.49 & Down-regulated & 0.042 \\
Continuous vs control & 2.08 & Down-regulated & $<0.001$ \\
NAC + single vs control & 1.01 & Down-regulated & 0.38 \\
NAC + continuous vs control & 1.47 & Down-regulated & 0.028 \\
Continuous vs Single & 1.40 & Down-regulated & 0.09 \\
Single vs NAC + continuous & 2.05 & Up-regulated & 0.006 \\
Single + NAC vs single & 1.47 & Up-regulated & 0.081 \\
Single + NAC vs continuous & 2.05 & Up-regulated & $<0.001$ \\
Single + NAC vs NAC + continuous & 1.46 & Up-regulated & 0.033 \\
Continuous + NAC vs continuous & 1.41 & Up-regulated & 0.042 \\
\hline
\end{tabular}

${ }^{*} P<0.05$ is considered as significant; One-Way ANOVA: Post Hoc-Tukey test was applied to compare mean value of Bcl2 expression pattern between all groups

caused a significant improvement in these parameters. More recently, Shraideh et al., [18] considered the relationship between occupational lead exposure and plasma levels of oxidative stress biomarkers. They found that $\mathrm{Pb}$ levels in the serum of these workers were significantly higher compared to control group ( $\sim 4-5$ times). While there was a significant decrease in the level of plasma GSH (16-25\%) and TAC value (21-33\%), the mean content of MDA $(120-333 \%)$ was significantly increased in the case of workers than controls [18]. Furthermore, there was $149-221 \%$ increase in hydrogen peroxide concentration, and 26-38\% increase in SOD activity in the case of workers compared to the control group. Dribben et al., [19] showed that $\mathrm{Pb}$ exposure triggers neuronal apoptosis in the developing mouse brain. $\mathrm{Xu}$ et al., [20] revealed that $\mathrm{Pb}$ exposure increases the level of histone acetylation and induces apoptosis in vascular and cardiac tissues. These data indicate that oxidative stress and overexpression of apoptotic mediators, which have been found in our study, seem to be a possible mechanism of $\mathrm{Pb}$ toxicity on kidney tissue; however, further studies are need to confirm this results.

According to these findings and the concepts of $\mathrm{Pb}$ pathogenesis on the kidney tissue, these might make a wise basis for the use of antioxidants that could protect renal cells from oxidative stress and apoptosis. Here, we considered the effect of NAC treatment to mitigate oxidative stress and renal cells 


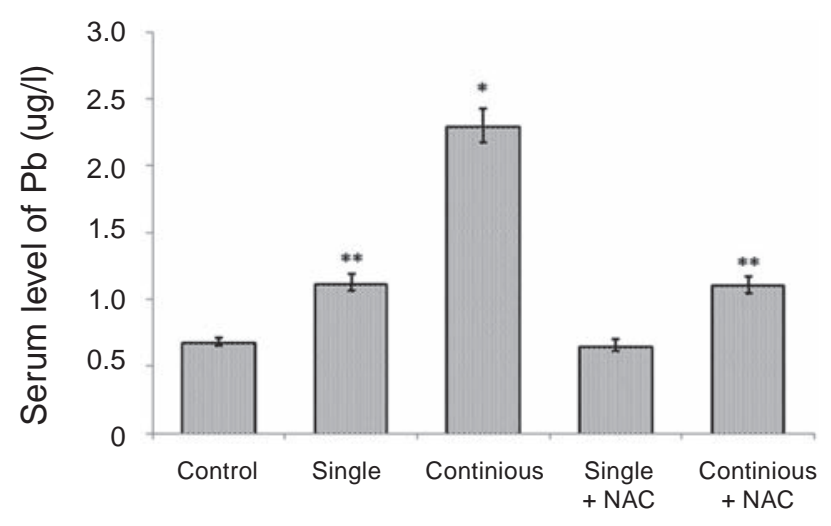

Fig. 6. Comparison of the mean of serum $\mathrm{Pb}$ levels in different groups. One-Way ANOVA: Post HocTukey test was applied to compare mean value of $\mathrm{Pb}$ between all groups. ${ }^{*}<0.001 ; * * P<0.01 \mathrm{com}-$ pared to control group

apoptosis caused by $\mathrm{Pb}$ effects. In our study, NAC treatment significantly decreased kidney cells injuries caused by $\mathrm{Pb}$. This effect was associated with a significant increase in total antioxidant capacity and a significant decrease in MDA contents in the kidney tissue. Interestingly, we found that NAC treatment not only improves the total antioxidants capacity, but also it attenuates oxidative stress, expression of Bax and increases anti-apoptotic Bcl2 in the kidney tissue of $\mathrm{Pb}$-treated rats. Although the level of oxidative stress biomarkers and expression of apoptotic factors in the kidney of rats exposed to continuous dose of $\mathrm{Pb}+\mathrm{NAC}$ were somewhat high, NAC improved these abnormalities in this group compared to rats that only treated with continuous dose of $\mathrm{Pb}$. These data indicate that NAC can be helpful in mitigating oxidative stress and renal cells apoptosis in subjects who chronically expose to $\mathrm{Pb}$. To support these findings, many studies revealed that NAC attenuates inflammation and oxidative stress by declining ROS production and apoptosis, as well as down-regulation of inflammatory cytokines and increasing of antiinflammatory mediators and antioxidants. A recent study has demonstrated that NAC treatment no only decreases Zearalenone (ZEN)-induced oxidative stress biomarkers and expression of Bax, Caspase 3 and Caspase 9, but also it improves the activity of GPX and glutathione reductase (GR) in vitro [21]. Yedjou et al., [22] reported that NAC supplementation protects hepatic cells against $\mathrm{Pb}$-induced cellular injury, genotoxicity and oxidative stress. Shieh et al., [23] have revealed that NAC treatment reversed malathion-induced oxidative stress responses, and

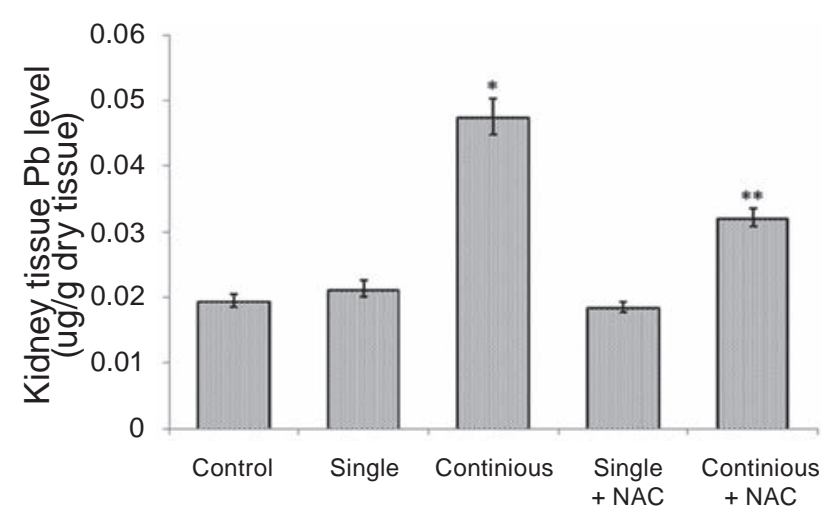

Fig. 7. Comparison of the mean of $\mathrm{Pb}$ levels in the kidney tissue of rats in different groups. OneWay ANOVA: Post Hoc-Tukey test was applied to compare mean value of $\mathrm{Pb}$ between all groups. ${ }^{*} P<0.001 ;{ }^{* *} P<0.01$ compared to control group

prevented malathion-evoked apoptosis by regulating apoptotic protein expressions (Bax, Bcl2, Caspases-3, and -9) in normal human astrocytes. Al-Nahdi et al., [24] revealed that NAC not only decreases streptozotocin-induced oxidative stress, but also inhibits DNA damage and expression of apoptotic proteins in pancreatic $\beta$-cells. In another study, Chen et al., [25] evaluated the effect of NAC treatment (150 $\mathrm{mg} / \mathrm{kg}$ ) against cadmium-induced neuronal apoptosis and oxidative stress in mice model. They found that continuous exposure to $\mathrm{Cd}(10-50 \mathrm{mg} / \mathrm{l})$ is significantly associated with overproduction of ROS, and brain damage or neuronal cell apoptosis. NAC treatment significantly prevented Cd-induced ROS production and attenuated Cd-induced brain damage or neuronal cell death by increasing the activities of $\mathrm{Cu} / \mathrm{Zn}$-superoxide dismutase, catalase and glutathione peroxidase, as well as the level of glutathione in the brain. Our findings were in agreement with these results. According to previous accomplished data and our findings, oxidative stress and apoptosis serve as common mediator of $\mathrm{Pb}$ cytotoxicity on kidney tissue. On the other hand, NAC supplementation declines the toxicity effects of $\mathrm{Pb}$ exposure.

Conclusion. In conclusion, the findings of the current study revealed that $\mathrm{Pb}$ exposure, especially continuous exposure to $\mathrm{Pb}$, is strongly associated with accumulation of $\mathrm{Pb}$, oxidative stress, antioxidant depletion, and kidney cells apoptosis. NAC can help protect kidney tissue against $\mathrm{Pb}$ by elevating antioxidants capacity, mitigating oxidative stress, as well as down-regulating of apoptotic factors. 
Conflict of interest. Authors have completed the Unified Conflicts of Interest form at http://ukrbiochemjournal.org/wp-content/uploads/2018/12/ coi_disclosure.pdf and declare no conflict of interest.

Acknowledgment. This work was supported by AJA University of Medical Sciences, Tehran, Iran. We would also like to appreciate Mr. Asghar Beigi Harchegani how helped us a lot in finalizing this project within the limited time frame.

Funding. This research was not funded by any organization and no grant has been acquired.

\section{ВПЛИВ N-АЦЕТИЛЦИСТЕЇНУ НА ОКСИДАТИВНИЙ СТРЕС ТА ЕКСПРЕСІЮ Вах I BCI2 В ТКАНИНІ НИРКИ ЩУРІВ ЗА ДІЇ СВИНЦЮ}

\author{
M. Gholami1 , A. B. Harchegani², S. Saeedian ${ }^{3}$, \\ M. Owrang ${ }^{4}$, M. R. Parvizi ${ }^{3 凶}$
}

${ }^{1}$ Department of Physiology, Faculty of Medicine, AJA University of Medical Sciences, Tehran, Iran; ${ }^{2}$ Department of Medical Genetics, Faculty of Medicine, Shahid Beheshti University of Medical Sciences, Tehran, Iran;

${ }^{3}$ Medical Genomic Research Center, Tehran Medicine Sciences

Islamic Azad University, Tehran, Iran;

${ }^{4}$ Faculty of Medicine, Sari Branch, Islamic Azad University, Sari, Iran;

凶e-mail: mparvizi@alumnus.tums.ac.ir

У роботі досліджували спричинене свинцем $(\mathrm{Pb})$ окисне пошкодження нирки щурів та роль антиоксиданту $\mathrm{N}$-ацетилцистеїну (NAC) у запобіганні токсичної дії $\mathrm{Pb}$ на клітини нирки. Щурів випадковим чином розділили на п'ять груп: G1 (контроль), G2 (разова доза 70 мг/кг $\mathrm{Pb}$ ), G3 (щоденне введення 2 мг/кг Рb протягом 4 тижнів), G4 (разова доза $\mathrm{Pb}+50$ мг/кг NAC) та $\mathrm{G} 5$ (щоденне введення $\mathrm{Pb}+50$ мг/кг NAC). Рівень $\mathrm{Pb}$ у сироватці та тканині нирок вимірювали методом атомноабсорбційної спектроскопії. Рівень малонового діальдегіду (MDA) та загальної антиоксидантної активності вимірювали спектрофотометрично. Експресію генів Bax та Bcl2 оцінювали за допомогою RT-PCR. Виявлено значне збільшення вмісту $\mathrm{Pb}$ у сироватці та нирковій тканині щурів у групах G2 та G3 порівняно з іншими групами як за одноразової, так і тривалої дії $\mathrm{Pb}$. За дії NAC спостерігали посилення антиоксидантної активності та зниження вмісту MDA у сироватці крові щурів, які зазнали впливу $\mathrm{Pb}$. Одноразове та тривале дозування $\mathrm{Pb}$ збільшувало експресію Вax у 3,9 та 13,1 раза та знижувало експресію Bcl2 у 1,5 та 2,1 раза в тканині нирки відповідно. Результати дослідження показують, що одноразова i більшою мірою тривала дія $\mathrm{Pb}$ пов'язані 3 накопиченням $\mathrm{Pb}$, виснаженням антиоксидантів, окисним стресом та апоптозом клітин нирок. Застосування NAC може допомогти захистити ниркову тканину від дії $\mathrm{Pb}$, підвищити його антиоксидантну здатність, зменшити оксидативний стрес та нормалізувати експресію генів Bax та Bcl2.

Кл юч ов і слова: свинець, нирки, $\mathrm{N}$-ацетилцистеїн, оксидативний стрес, Bax, Bcl2, апоптоз.

\section{References}

1. da Silva RF, Borges Cdos S, Villela E Silva P, Missassi G, Kiguti LRA, Pupo AS, Barbosa Junior F, Anselmo-Franci JA, Kempinas Wde G. The Coadministration of N-Acetylcysteine Ameliorates the Effects of Arsenic Trioxide on the Male Mouse Genital System. Oxid Med Cell Longev. 2016; 2016: 4257498.

2. Hou S, Yuan L, Jin P, Ding B, Qin N, Li L, LiuX, Wu Z, Zhao G, Deng Y. A clinical study of the effects of lead poisoning on the intelligence and neurobehavioral abilities of children. Theor Biol Med Model. 2013; 10: 13.

3. Vij AG. Hemopoietic, hemostatic and mutagenic effects of lead and possible prevention by zinc and vitamin C. Al Ameen J Med Sci. 2009; 2 (2 Special): 27-36.

4. Shahsavarani A, McNeill B, Galvez F, Wood CM, Goss GG, Hwang PP, Perry SF. Characterization of a branchial epithelial calcium channel (ECaC) in freshwater rainbow trout (Oncorhynchus mykiss). $J$ Exp Biol. 2006; 209(Pt 10): 1928-1943.

5. Perry SF, Furimsky M, Bayaa M, Georgalis T, Shahsavarani A, Nickerson JG, Moon TW. Integrated responses of $\mathrm{Na}^{+} / \mathrm{HCO}_{3}^{-}$cotransporters and V-type $\mathrm{H}^{+}$-ATPases in the fish gill and kidney during respiratory acidosis. Biochim Biophys Acta. 2003;1 618(2): 175-184.

6. Perry SF, Shahsavarani A, Georgalis T, Bayaa M, Furimsky M, Thomas SLY. Channels, pumps, and exchangers in the gill and kidney of freshwater fishes: their role in ionic and acid-base regulation. $J$ Exp Zool A Comp Exp Biol. 2003; 300(1): 53-62. 
7. Flora G, Gupta D, Tiwari A. Toxicity of lead: A review with recent updates. Interdiscip Toxicol. 2012; 5(2): 47-58.

8. Mahdavi LS, et al. Effects of intraperitoneal administration of cadmium on apoptotic Bcl-2 and Bax genes expression in rat hippocampal cells. Novin Genetic. 2017; 12: 81-89.

9. Ilkhani M, et al. Core Ways on Cancer Patients. Tehran: Ghazi Jahani Pub. 1990.

10. Hemalatha P, Reddy AG, Reddy YR, Shivakumar P. Evaluation of protective effect of $\mathrm{N}$-acetyl cysteine on arsenic-induced hepatotoxicity. J Nat Sci Biol Med. 2013; 4(2): 393-395.

11. Dekhuijzen PNR. Antioxidant properties of $\mathrm{N}$-acetylcysteine: their relevance in relation to chronic obstructive pulmonary disease. Eur Respir J. 2004; 23(4): 629-636.

12. Hajighasem A, Farzanegi P, Mazaheri Z. Effects of combined therapy with resveratrol, continuous and interval exercises on apoptosis, oxidative stress, and inflammatory biomarkers in the liver of old rats with non-alcoholic fatty liver disease. Arch Physiol Biochem. 2019;125(2):142-149.

13. Ma Z, Chu L, Liu H, Wang W, Li J, Yao W, Yi J, Gao Y. Beneficial effects of paeoniflorin on nonalcoholic fatty liver disease induced by high-fat diet in rats. Sci Rep. 2017; 7: 44819.

14. Benzie IF. Lipid peroxidation: a review of causes, consequences, measurement and dietary influences. Int J Food Sci Nutr. 1996; 47(3): 233-261.

15. Rao B, Soufir JC, Martin M, David G. Lipid peroxidation in human spermatozoa as related to midpiece abnormalities and motility. Gamete Res. 1989; 24(2): 127-134.

16. Babiker F, Al-Kouh A, Kilarkaje N. Lead exposure induces oxidative stress, apoptosis, and attenuates protection of cardiac myocytes against ischemiareperfusion injury. Drug Chem Toxicol. 2019; 42(2): 147-156.

17. Kumar MR, Reddy AG, Anjaneyulu Y, Reddy GD. Oxidative stress induced by lead and antioxidant potential of certain adaptogens in poultry. Toxicol Int. 2010; 17(2): 45-48.

18. Shraideh Z, Badran D, Hunaiti A, Battah A. Association between occupational lead exposure and plasma levels of selected oxidative stress related parameters in Jordanian automobile workers. Int $J$ Occup Med Environ Health. 2018; 31(4): 517-525.

19. Dribben WH, Creeley CE, Farber N. Low-level lead exposure triggers neuronal apoptosis in the developing mouse brain. Neurotoxicol Teratol. 2011; 33(4): 473-480.

20. Xu LH, Mu FF, Zhao JH, He Q , Cao CL, Yang H, Liu Q, Liu XH, Sun SJ.Lead Induces Apoptosis and Histone Hyperacetylation in Rat Cardiovascular Tissues. PLoS One. 2015; 10(6): e0129091.

21. Wang J, Li M, Zhang W, Gu A, Dong J, Li J, Shan A. Protective Effect of N-Acetylcysteine against Oxidative Stress Induced by Zearalenone via Mitochondrial Apoptosis Pathway in SIEC02 Cells. Toxins (Basel). 2018; 10(10): 407.

22. Yedjou CG, Waters D, Tchounwou PB. N-Acetylcysteine Protection Against Lead-Induced Oxidative Stress and Genotoxicity in Human Liver Carcinoma (HepG 2) Cells. Met Ions Biol Med. 2008; 10: 419424.

23. Shieh $P$, Jan CR, Liang WZ. The protective effects of the antioxidant $\mathrm{N}$-acetylcysteine (NAC) against oxidative stress-associated apoptosis evoked by the organophosphorus insecticide malathion in normal human astrocytes. Toxicology. 2019; 417: 1-14.

24. Al-NahdiAMT, John A, Raza H. Cytoprotective Effects of N-Acetylcysteine on StreptozotocinInduced Oxidative Stress and Apoptosis in RIN5F Pancreatic $\beta$-Cells. Cell Physiol Biochem. 2018; 51(1): 201-216.

25. Chen S, Ren Q, Zhang J, Ye Y, Zhang Z, Xu Y, Guo M, Ji H, Xu C, Gu C, Gao W, Huang S, Chen L. N-acetylL-cysteine protects against cadmium-induced neuronal apoptosis by inhibiting ROS-dependent activation of Akt/mTOR pathway in mouse brain. Neuropathol Appl Neurobiol. 2014; 40(6): 759-777. 